\title{
KESULITAN BELAJAR MATEMATIK SISWA SEKOLAH DASAR PADA OPERASI HITUNG BILANGAN BULAT
}

\author{
Geri Syahril Sidik \\ Program Studi Pendidikan Guru Sekolah Dasar, Fakultas Keguruan dan Ilmu Pendidikan, \\ Universitas Perjuangan Tasikmalaya, \\ Email: gerisyahril@unper.ac.id \\ Agus Ahmad Wakih \\ Program Studi Pendidikan Guru Sekolah Dasar, Fakultas Keguruan dan Ilmu Pendidikan, \\ Universitas Perjuangan Tasikmalaya, \\ Email: agus.aw.unper@gmail.com
}

\begin{abstract}
The elementary schools nowadays show that there are still found many students who have difficulty math study, especially on arithmetic operations of integers. This study aims to obtain the difficulty of learning mathematics elementary school student. That information will be used as material in drafting a solution to reduce the student's difficulties. This research is a qualitative descriptive study. Students in first grade are given a worksheet to solve individually by writing out the work steps clearly. Six students were chosen as research subjects to be analyzed. The sixth research subject consists of 2 subjects who have high mathematical abilities, 2 medium, and 2 low mathematical abilities. The difficulty of the subject was observed by examining the worksheet's answer and giving clinical interviews related to the results of his work. Based on the results of data analysis, the difficulty of learning mathematics of elementary school students in integer operations is: 1) students have difficulty understanding the purpose of the question so that it incorrectly translated into mathematical sentences; 2) students have difficulty operating numbers that contain negative signs; 3) $85 \%$ of students have difficulty understanding the meaning of equal sign "="; 4) students have difficulty carrying out the division operations and 5) students have difficulty understanding the meaning of the parenthesis symbol "()".
\end{abstract}

Keywords:

Mathematics learning difficulties; the operations of integers, the elementary student

\begin{abstract}
Abstrak
Kondisi di sekolah dasar sekarang ini masih banyak ditemukan siswa yang mengalami kesulitan belajar khususnya materi operasi hitung bilangan bulat. Penelitian ini bertujuan untuk memperoleh gambaran kesulitan belajar matematik siswa sekolah dasar. Informasi tersebut kemudian akan digunakan sebagai bahan dalam membuat rancangan penyelesaian untuk mengurangi kesulitan yang dihadapi siswa. Penelitian ini merupakan penelitian deskriptif kualitatif. Siswa dalam satu kelas diberikan lembar tugas untuk dikerjakan secara individu dengan menuliskan langkah-langkah kerja secara jelas. Dipilih 6 siswa sebagai subjek penelitian untuk dianalisis. Terdiri dari 2 subjek yang memiliki kemampuan matematika tinggi, 2 sedang dan 2 rendah. Kesulitan subjek diamati dengan mencermati dan mengkaji jawaban lembar tugas serta memberikan wawancara klinis terkait hasil pekerjaannya. Berdasarkan hasil analisis data diperoleh kesulitan belajar matematika siswa sekolah dasar pada operasi bilangan bulat adalah: 1) siswa kesulitan memahami maksud soal sehingga salah menerjemahkan ke kalimat matematika; 2) siswa kesulitan mengoperasikan bilangan yang memuat tanda negatif; 3) 85\% siswa kesulitan memahami makna sama dengan “=”; 4) siswa kesulitan melakukan operasi hitung pembagian dan 5) siswa kesulitan memahami makna lambang tanda kurung "()".
\end{abstract}

Kata kunci:

Kesulitan belajar matematik; operasi hitung bilangan bulat, siswa sekolah dasar

\section{A. Pendahuluan}

Tujuan diajarkannya matematika di sekolah dasar yaitu supaya siswa mampu memahami konsep matematika, menjelaskan keterkaitan antar konsep dan mengaplikasikan konsep atau algoritma secara luwes, akurat, efisien dan tepat dalam pemecahan masalah kehidupan sehari-hari ${ }^{1}$. Salah satu materi yang dipelajari adalah operasi

${ }^{1}$ Permendiknas RI nomor 22 tahun 2006 tentang

standar isi untk satuan pendidikan dasar dan menengah. hitung (penjumlahan, pengurangan, perkalian dan pembagian) pada bilangan bulat. Materi ini mulai diajarkan pada siswa kelas IV Sekolah Dasar. Siswa dituntut harus menguasai materi ini, karena materi ini akan menunjang keberlangsungan pembelajaran selanjutnya.

Sejauh ini siswa masih banyak mengalami kesulitan dalam pembelajaran materi operasi bilangan bulat. Biasanya siswa mengalami 
kesulitan pada saat mengerjakan soal cerita ${ }^{2}$. Soalsoal yang berkaitan dengan bilangan tidaklah begitu menyulitkan siswa, namun soal-soal yang menggunakan kalimat, sangat menyulitkan bagi siswa yang kurang memiliki kemampuan dalam berhitung ${ }^{3}$ Kesulitan biasanya terjadi pada tahap pemahaman soal terkait penyelesaian permasalahan konstektual dan saat melakukan operasi hitung yang berkaitan dengan bilangan bulat $^{4}$. Kesulitan memahami soal akan mengakibatkan siswa salah menerjemahkan soal kedalam kalimat matematika ${ }^{5}$. Penyebab siswa salah menyelesaikan soal cerita antara lain siswa belum memahami konsep, menggunakan proses yang keliru, ceroboh memahami maksud soal, kurang memahami konsep prasyarat, dan salah dalam perhitungan ${ }^{6}$. Hal ini menunjukkan bahwa siswa belum mampu menyelesaikan soal pemahaman relasional yaitu soal yang menunjukkan kemampuan siswa dalam menguasai suatu konten yang dikaitkan dengan konten yang lain kemudian menyelesaikannya ${ }^{7}$.

Upaya telah dilakukan untuk memecahkan permasalahan kesulitan belajar siswa, diantaranya dengan belajar tambahan, remedial, bahkan yang menggunakan model pembelajaran yang dianggap modern. Penggunaan model pembelajaran belum cukup untuk memberikan solusi dari kesulitan belajar siswa. Seseorang dapat diduga mengalami kesulitan belajar jika yang bersangkutan tidak berhasil mencapai taraf kualifikasi hasil belajar tertentu (berdasarkan kriteria dalam tujuan

2 Untari, E. (2013). Diagnosis kesulitan belajar pokok bahasan pecahan pada siswa kelas $\mathrm{V}$ sekolah dasar. Jurnal IImiah STKIP PGRI Ngawi, 13(01), hal. 1-8.

3 Soekisno, B.A.R, (2002), Kemampuan Pemahaman Matematik Matematika Siswa Dengan Strategi Heuristik. (Tesis). Sekolah Pascasarjana, Universitas Pendidikan Indonesia.

${ }^{4}$ Sidik, G, S. (2016). Analisis Proses Berpikir Dalam Pemahaman Matematis Siswa Sekolah Dasar Dengan Pemberian Scaffolding. Untirta. JPSD, 2 (2), hal. 192-204.

${ }^{5}$ Sidik, G.S., Nugraha, F., \& Ferisa, D. (2017). Analisis Proses Berpikir Siswa Sekolah Dasar Dalam Memahami Aplikasi Operasi Hitung Matematika Dengan pemberian Scaffolding. Jurnal Forum Didaktik, Vol I No 1, 1-7. Universitas Perjuangan Tasikmalaya.

${ }^{6}$ Untari, E. (2013). Diagnosis kesulitan belajar pokok bahasan pecahan pada siswa kelas $\mathrm{V}$ sekolah dasar. Jurnal IImiah STKIP PGRI Ngawi, 13(01), hal. 1-8.

7 Skemp, R. (2006). Relational Understanding and Instrumental Understanding. Journal of Mathematics Teaching in The Middle School, 12 (2), hal. 88-95. instruksional atau ukuran kapasitas belajarnya) dalam batas waktu tertentu ${ }^{8}$. Pembelajaran yang dilakukan belum memahami perbedaan siswa secara individu dan belum melayani pembelajaran yang sesuai dengan perbedaannya itu. Siswa akan berkembang sesuai dengan kemampuannya masing-masing. Perbedaan individual ini berpengaruh pada cara dan hasil belajar siswa. Perbedaan individu perlu diperhatikan oleh guru dalam upaya perbaikan pembelajaran. Pembelajaran yang dilakukan tidak menyadari bahwa kesulitan-kesulitan yang dihadapi siswa disebabkan oleh kurangnya perhatian, pemahaman dan peran guru di dalam proses pembelajaran. Nilai rendah yang diperoleh siswa dalam ujian menandakan siswa belum berhasil menguasai materi atau mengalami kesulitan dalam belajarnya ${ }^{9}$.

Perlu adanya kajian secara mendalam mengenai kesulitan seperti apa yang dialami oleh siswa pada penguasaan materi operasi hitung bilangan bulat. Seiring dengan diketahuinya kesulitan belajar yang dialami siswa, diharapkan akan menjadi gambaran bahan dalam membat rancangan penyelesaian supaya kesulitan yang siswa hadapi semakin berkurang.

Penelitian ini merupakan penelitian deskriptif kualitatif. Penelitian dilakukan di satu kelas pada pembelajaran matematika dengan materi operasi hitung bilangan bulat. Seluruh siswa kelas V diberikan dua jenis lembar tugas bentuk kalimat matematika langsung dan soal cerita untuk dikerjakan secara individu dengan menuliskan langkah-langkah kerja secara jelas terkait materi operasi hitung bilangan bulat dalam waktu yang berbeda. Pemberian kedua jenis lembar tugas tersebut diharapkan dapat lebih menggali letak kesulitan siswa dalam menyelesaikan operasi hitung bilangan bulat. Dipilih enam siswa sebagai subjek penelitian untuk dianalisis, terdiri dari dua subjek yang memiliki kemampuan matematika tinggi $\left(\mathrm{S}_{1} \& \mathrm{~S}_{2}\right)$, dua sedang $\left(\mathrm{S}_{3} \& \mathrm{~S}_{4}\right)$ dan dua rendah $\left(\mathrm{S}_{5} \& \mathrm{~S}_{6}\right)$. Penetapan katagori kemampuan matematika subjek didasarkan pada skor hasil lembar tugas yang diberikan, nilai matematika pada raport sebelumnya, serta masukan dari wali

8 Mulyadi. (2010). Diagnosis Kesulitan Belajar. Yogyakarta: Nuha Litera.

9 Irham, M. (2014). Psikologi Pendidikan Teori dan Aplikasi dalam Proses Pembelajaran. Yogyakarta: Ar-ruz Media. 
kelas. Hasil temuan dalam penelitian dilanjutkan pada pembahasan melalui Focus Group Discussion (FGD).

\section{B. Hasil dan Pembahasan}

Berdasarkan hasil analisis jawaban lembar tugas siswa, ditemukan bahwa pada umumnya siswa: 1) kesulitan mengoperasikan bilangan yang memuat tanda negatif; 2) kesulitan menerjemahkan maksud soal ke dalam kalimat matematika; 3) kesulitan memahami makna lambang sama dengan "="; 4) kesulitan dalam melakukan operasi hitung pembagian; 5) kesulitan memahami makna lambang tanda kurung "()". Berikut ini akan dijelaskan secara lebih terperinci mengenai hasil temuan dan analisis kesulitan matematik siswa sekolah dasar sebagaimana yang disebutkan diatas terutama dalam menyelesaikan dua jenis soal baik soal bentuk kalimat matematika langsung dan soal cerita pada materi operasi hitung bilangan bulat.

\section{Kesulitan menerjemahkan maksud soal ke dalam kalimat matematika}

Kesulitan menerjemahkan maksud soal kedalam kalimat matematika diawali dengan kesulitan siswa memahami maksud soal. Seringkali kesulitan memahami maksud soal ini menyebabkan mereka tidak dapat menyelesaikan soal. Kesulitan dalam memahami dan menerjemahkan soal ke dalam kalimat atau bentuk matematika ini seringkali ditemukan dalam penyelesaian soal cerita. Menghadapi soal matematika khususnya soal cerita, siswa harus lebih dahulu melakukan analisis dan interpretasi informasi untuk kemudian dijadikan landasan dalam menentukan pilihan dan keputusan penyelesaian suatu soal matematika. Siswa harus menguasai cara mengaplikasikan konsep-konsep matematika dan menggunakan ketrampilan berhitung matematika atau komputasi dalam menyelesaikan soal. Kesulitan dalam memahami dan menerjemahkan maksud soal ke dalam kalimat matematika ini jika dianalisis merupakan soal rangkap dan berurut, sehingga satu keterampilan akan menjadi prasyarat untuk keterampilan berikutnya dalam penyelesaian masalah matematika. Urutannya yaitu, siswa harus memiliki kemampuan memahami permasalahan kemudian menerjemahkan dalam bentuk matematika sehingga dibutuhkan penguasaan konsep dan harus ditunjang dengan kemampuan komputasi. Kesulitan dalam menerjemahkan soal ke dalam bentuk matematika ini seringkali berkaitan dengan memecahkan persoalan yang berbentuk cerita berarti menerapkan pengetahuan yang dimiliki secara teoritis untuk menyelesaikan persoalan nyata dalam kehidupan sehari-hari. Hal tesebut sesuai dengan beberapa pendapat yang menyatakan bahwa kesulitan dalam mengerjakan soal cerita disebabkan karena siswa kurang cermat dalam membaca dan memahami kalimat demi kalimat serta mengenai apa yang diketahui dalam soal dan apa yang ditanyakan, serta bagaimana cara menyelesaikan soal secara tepat (Muncarno, 2008; Paridjo, 2012: 7; Kartikasari, 2017) ${ }^{101112}$

Kesulitan dalam memahami maksud soal dan menerjemahkannya ke dalam kalimat matematika dialami oleh semua subjek. Berikut ini adalah beberapa gambarannya:
10 Muncarno. (2008). Penerapan Model Penyelesaian Soal Cerita dengan Langkah-langkah Pemecahan Masalah untuk Meningkatkan Prestasi Belajar Matematika Siwa Kelas I SMP. Jurnal Nuansa Pendidikan, Vol.6 No. 1.

11 Paridjo. (2012). Sebuah Solusi Mengatasi Kesulitan Belajar Matematika. Semarang: Universitas Terbuka.

12 Kartikasari, Respina. (2017). Analisis Kesulitan Siswa dalam Menyelesaikan Soal Cerita Matematika Pada Siswa SMP. Jurnal Program Studi Pendidikan Matematika Fakultas Keguruan dan IImu Pendidikan Universitas Muhammadiyah Surakarta. 
1. Suhu didalam lemari es $\left(-6^{\circ}\right) \mathrm{C}$, sedangakan Suhu diluar lemari es $29^{\circ} \mathrm{C}$. Berapa selisih suhu dari kedua tempat tersebut?

Jawah:

$$
\left(-6^{\circ}\right) C-29^{\circ} c=\left(-23^{\circ} \mathrm{C}\right.
$$

Gambar 1. Kesulitan memahami maksud soal ( $\mathrm{S}_{1}$ pada soal no 1)

Dari gambar 1, terlihat $\mathrm{S}_{1}$ salah membuat $29-(-6)$. Akibatnya jawaban $\mathrm{S}_{1}$ tidak sesuai kalimat matematika. Seharusnya selisih itu adalah dengan permintaan soal.

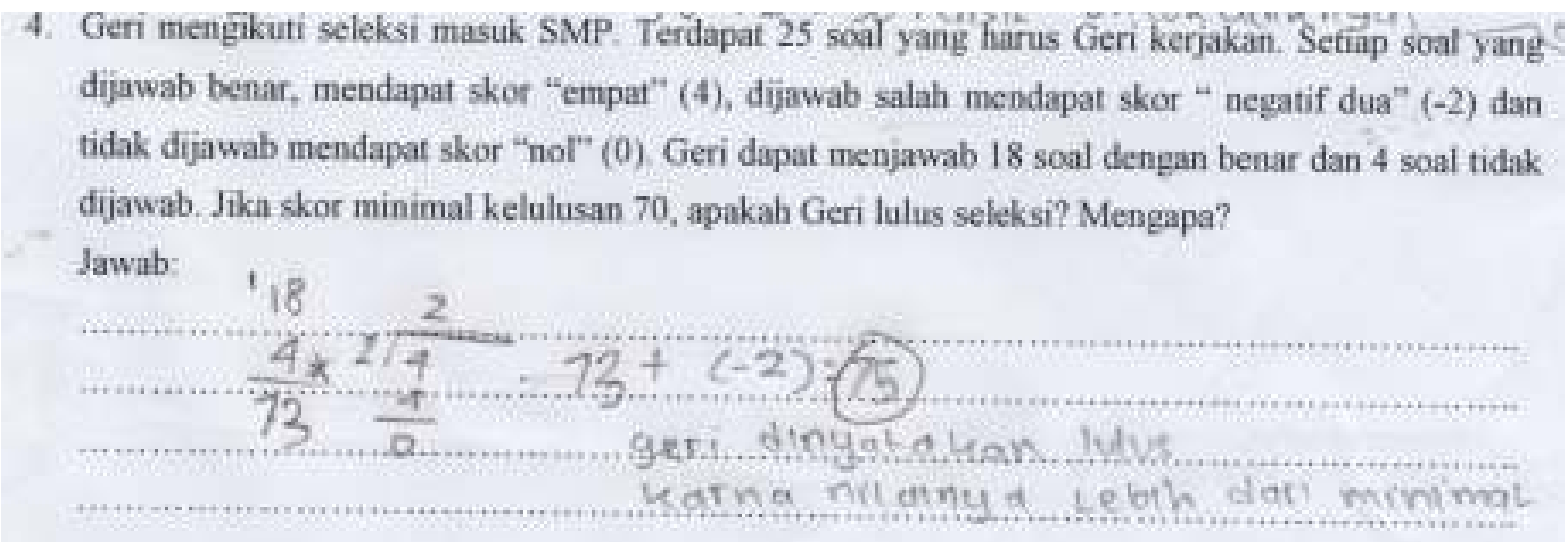

Gambar 2. Kesulitan memahami maksud soal ( $\mathrm{S}_{1}$ soal no 4)

Dari gambar 2, dapat diketahui bahwa $\mathrm{S}_{1}$ tidak memahami maksud soal secara utuh. $\mathrm{S}_{1}$ kurang cermat dalam memahami kalimat mengenai: 1) apa yang diketahui dalam soal, 2) apa yang ditanyakan, 3) informasi yang tersembunyi, serta 4) bagaimana cara menyelesaikan soal secara tepat. Informasi yang seharusnya diketahui dari soal adalah jika soal dijawab dengan benar maka dikalikan dengan berapa dan jika soal dijawab salah dikalikan dengan bilangan negatif serta informasi tentang skor batas kelulusan. $\mathrm{S}_{1}$ kesulitan memahami informasi yang ditanyakan pada soal yaitu tentang "apakah Geri lulus? Mengapa?" Akhirnya jawaban $\mathrm{S}_{1}$ tidak sesuai dengan keinginan soal. Seharusnya $S_{1}$ mengetahui banyaknya soal yang dijawab "salah". Jadi penyelesaiannya jawaban benar dikali 4, dikurangi nol " 0 " (dari hasil yang tidak dijawab), dan dikurangi hasil soal yang dijawab salah dikalikan $(-2)$.

1. Suhu didalam lemari es $\left(-6^{\circ}\right) \mathrm{C}$, sedangakan Suhu diluar leuan es $29^{\circ} \mathrm{C}$. Bermpa selisilt suhu dari kedua tompat tersehut?

Sawab:

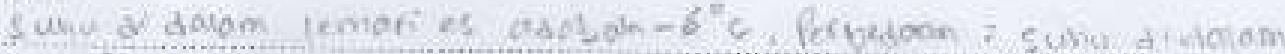

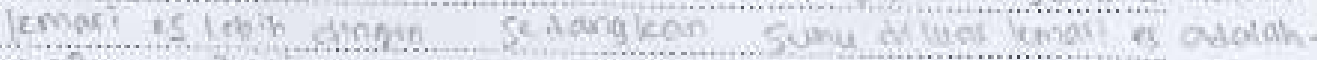

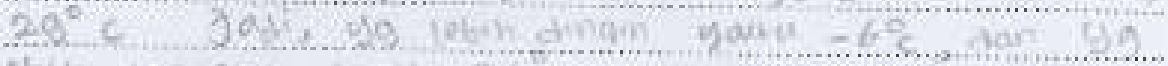

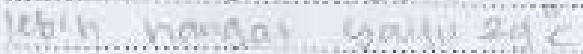


2. Prk Eko mempunyai 6 karung buah Jambu kristal Masing-nasug karung berisi 300 buab. Jumbujambu tersebut akan dimasukan ke dalan kenunjang masing-masmy dapat diisi 30 baah Berapa banyak kerangang yaur banis disedakan pak Eko?

Jawab:

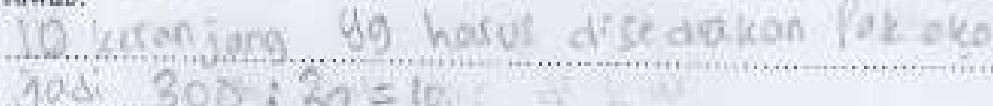

3. Yosi mempunyai 6 brah bukn tulis dan 2 buah pensi Kenudian da membeli 2 losin buku tulis dan 4 lusia peasil. Sebanynk 3 bual buku dan 5 bual pensil Yosi diberikan kepada adikuya. Selebihnya buku daa pensu tersebut dibagikan kepads \& anak. Beraps banyak jumlah triku dan peasil yany diterima masing-nassmg anak?

Jawab:

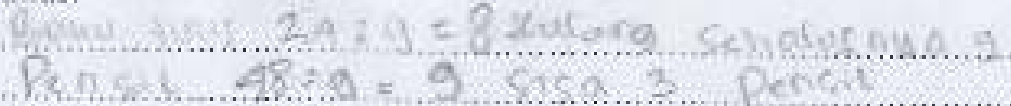

Gambar 3. Kesulitan memahami maksud soal ( $\mathrm{S}_{3}$ soal no 1, 2 dan 3)

Dari gambar 3, terlihat $\mathrm{S}_{3}$ tidak memahami maksud soal, akibatnya keliru memberikan jawaban. Jawaban $S_{3}$ pada soal no 1 dalam kenyataanya memang benar bahwa $\left(-6^{0}\right) \mathrm{C}$ itu lebih dingin daripada $29^{\circ} \mathrm{C}$. Namun itu bukan permintaan soal. Seharusnya kalimat matematika yang sesuai dengan soal no 1 adalah $29-(-6)=$ 35. Jawaban $\mathrm{S}_{3}$ untuk no 2 dan no 3 terlihat jelas bahwa apa yang diminta soal tidak sesuai dengan jawaban yang diberikan. Artinya $\mathrm{S}_{3}$ belum memahami maksud soal sehingga salah menuangkannya dalam kalimat matematika. Seharusnya untuk no $2, \mathrm{~S}_{3}$ menjawab $(6 \times 300)$ : $30=60$. Jawaban $\mathrm{S}_{3}$ untuk no 3 adalah $(6+(2 \times$ $12)-3)=3$ dan $(2+(4 \times 12)-9)=5$.

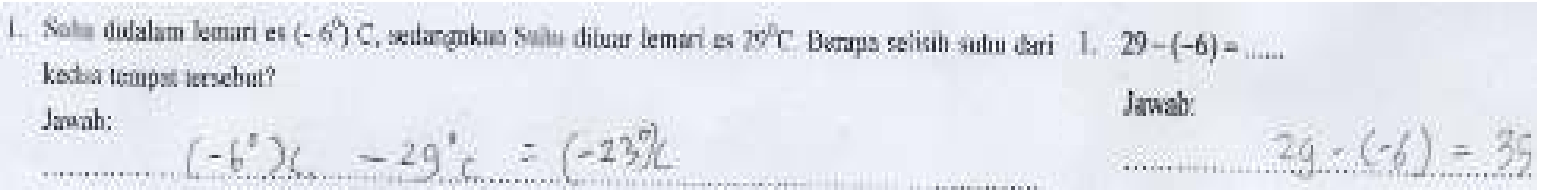

Gambar 4. Perbandingan jawaban $\mathrm{S}_{1}$ pada soal bentuk cerita dan bentuk kalimat matematika langsung

Gambar 5 menunjukkan bahwa $\mathrm{S}_{1}$ kesulitan menerjemahkan soal cerita kedalam kalimat matematika sehingga jawaban tidak sesuai permintaan soal. Tetapi $S_{1}$ dapat menyelesaikan soal yang berbentuk kalimat matematika langsung dengan baik. Hal seperti ini dialami oleh semua subjek. Menunjukan bahwa subjek belum memiliki proses berpikir relasional instrumental yang baik, yaitu proses berpikir yang melibatkan kemampuan mengaitkan konteks cerita kedalam kalimat matematika, kemudian menyelesaikan perhitungan (Sidik, 2019) ${ }^{13}$

13 Sidik, G. S., \& Nugraha, F. (2019). Proses Berpikir pada Pemahaman Matematik Siswa Sekolah Dasar Terkait Materi Operasi Hitung Perkalian dan Pembagian Pecahan [The Process of Thinking in Mathematical Understanding of Primary School Students Regarding Counting Operation Materials Multiplicat. PEDAGOGIA: Jurnal Pendidikan, 8(1), 45-52.
Berdasarkan gambaran yang sudah dipaparkan disimpulkan bahwa kesulitan dalam memahami soal dan menerjemahkan soal ke dalam kalimat matematika akan selalu terkait dengan kemampuan memahami 1) apa yang diketahui dalam soal, 2) apa yang ditanyakan, 3) bagaimana cara menyelesaikan soal secara tepat, 4) penguasaan konsep sehingga mampu menerjemahkan dalam bentuk matematik serta harus ditunjang dengan 5) kemampuan komputasi.

\section{Kesulitan mengoperasikan bilangan yang memuat tanda negatif}

Berdasarkan jawaban pada lembar tugas, hanya $\mathrm{S}_{2}$ yang dapat menjawab sesuai permintaan soal. Subjek mengalami kesulitan dalam mengoperasikan bilangan yang memuat tanda negatif. Subjek tidak memahami esensi dari bilangan negatif. 
1. Suhu didalam lemari es $\left(-6^{0}\right) \mathrm{C}$, sedangakan Sulu diluar lemari es $29^{0} \mathrm{C}$. Berapu selisih suhu dari kedua tempat tersebut?

Jawab:

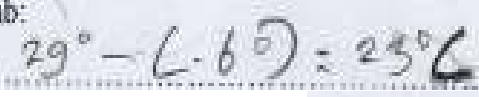

1. $29-(-61=\ldots .$.
Jawab

23

Gambar 5. Kesulitan subjek mengoperasikan bilangan bertanda negatif

Berdasarkan jawaban yang terlihat pada gambar 5, subjek menjawab 23. Subjek langsung menghitung 29 $-6=23$, tanpa memahami arti (-6). Pemikiran seperti ini terjadi pada $\mathrm{S}_{1}$ dan $\mathrm{S}_{4}$.

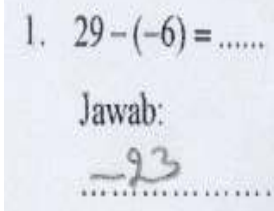

Gambar 6. Kesulitan subjek mengoperasikan bilangan bertanda negatif

Berdasarjan jawaban yang terlihat pada gambar 6, subjek menjawab (-23). Subjek langsung menghitung $29-6=23$ dengan mempertimbangkan tanda negatif. Pemikiran seperti ini terjadi pada $S_{3}$.

$$
\begin{aligned}
& \text { 1. } 29-(-6)=\frac{33}{23} \\
& \text { Jawab: } \\
& 29-(-6) \cdot \frac{29}{23}+\frac{6}{25}=\frac{23}{23}
\end{aligned}
$$

Gambar 7. Kesulitan subjek mengoperasikan bilangan bertanda negatif

Berdasarkan jawaban yang terlihat pada gambar 7, subjek cenderung asal dalam menjawab. Subjek tidak memahami makna pengurangan dengan bilangan negatif dan hanya menuliskan angka-angka yang muncul dalam soal. Pemikiran seperti ini terjadi pada $\mathrm{S}_{5}$ dan $\mathrm{S}_{6}$. Beberapa temuan jawaban, terlihat bahwa subjek cenderung kurang memahami prinsip atau sifat dalam operasi hitung bilangan yang memuat tanda negatif.

\section{Kesulitan dalam memahami makna lambang sama dengan $(=)$}

Hasil analisis lembar jawaban subjek, ditemukan kesulitan dalam memahami makna lambang sama dengan $(=)$. Kecenderungan kesulitan memahami makna lambang sama dengan ini bahkan ditemukan pada $85 \%$ jawaban keseluruhan. Gambaran kesulitan subjek dalam memahami makna lambang sama dengan dapat terlihat pada gambar di bawah ini:

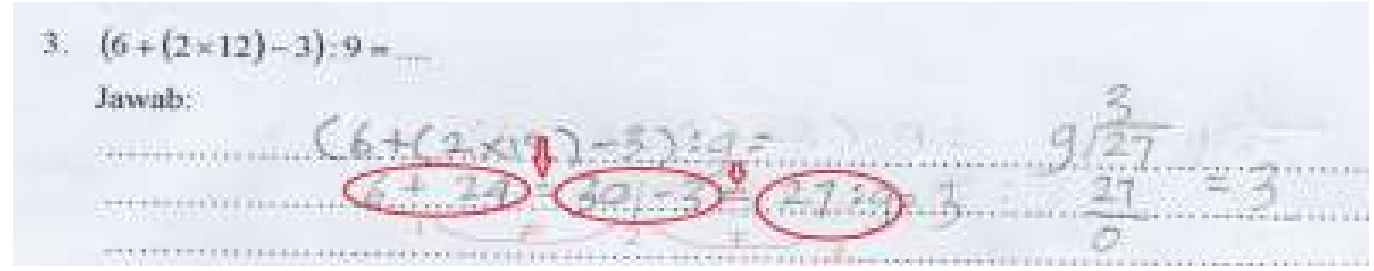




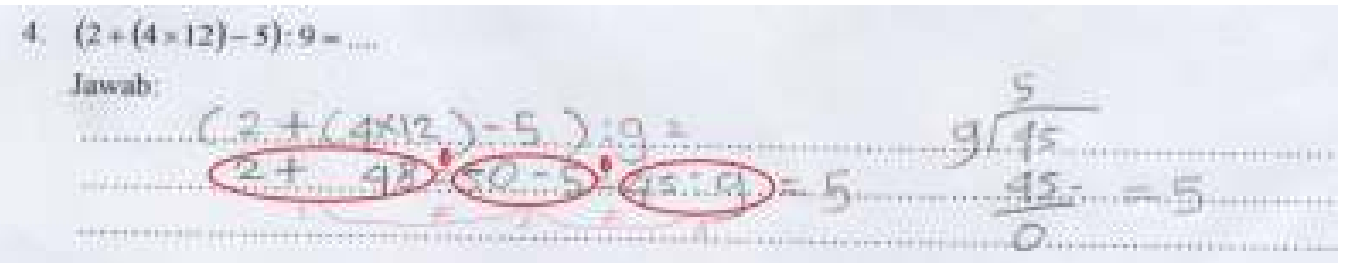

Gambar 8. Kesalahan memahami makna lambang sama dengan (=)

Berdasarkan gambar 8, dapat kita lihat bahwa ada kekeliruan dalam penggunaan tanda sama dengan. Perhatikan jawaban no 3 pada gambar 8 . Subjek menuliskan $6+24=30-3$. Selanjutnya $30-3=27: 9$ dan secara tidak langsung $6+24=$ 27 : 9. Jika di maknai, $6+24$ tidak sama dengan $30-3$, begitupun $30-3$ tidak sama dengan 27 : 9 dan $6+24$ tidak sama dengan $27: 9$. Perhatikan jawaban no 4 pada gambar 8 . Subjek menuliskan $2+48=50-5,50-5=45: 9$ dan secara tidak langsung $2+48=45: 9$. Jika di maknai, $2+48$ tidak sama dengan $50-5,50-5$ tidak sama dengan 45 : 9 dan $2+48$ tidak sama dengan 45 : 9. Jawaban akhir subjek memang sesuai dengan permintaan soal, namun jika dimaknai, kalimat matematika yang ditulis subjek keliru.

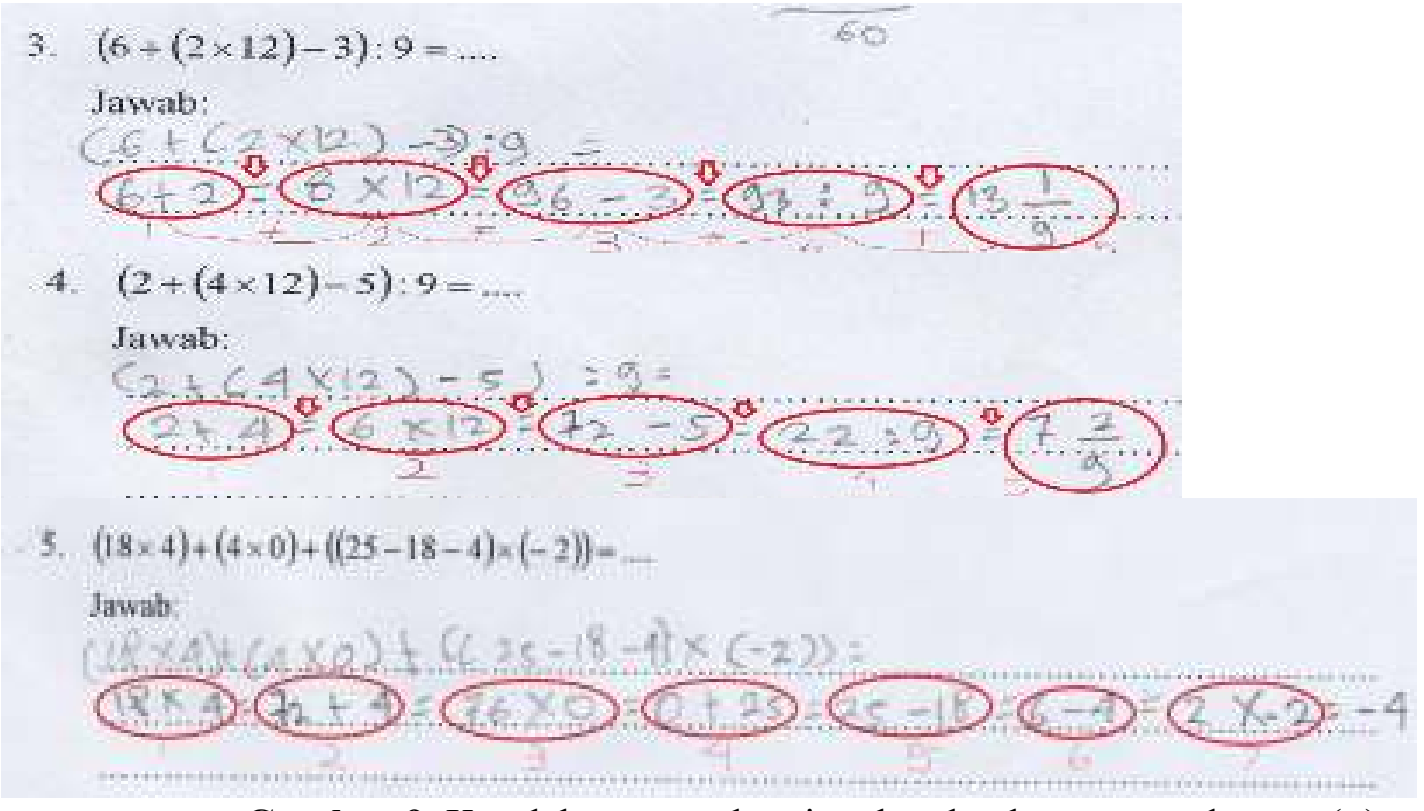

Gambar 9. Kesalahan memahami makna lambang sama dengan $(=)$

Berdasarkan gambar 9, dapat kita lihat bahwa ada kekeliruan dalam penggunaan tanda sama dengan. Perhatikan semua yang dilingkari. Ruas kiri dan ruas kanan yang dihubungkan oleh tanda sama dengan tidak berimbang. Sama dengan berarti ruas kiri dan kanan nilainya harus sama walapun bentuknya berbeda.

\section{Kesulitan dalam melakukan operasi hitung pembagian}

Kesulitan lain yang ditemukan adalah sulit melakukan operasi hitung pembagian. Semua subjek mengalami kesulitan dalam melakukan operasi hitung pembagian. Ada subjek yang memahami makna dan prosedur operasi pembagian, namun salah dalam perhitungan, ada juga subjek yang tidak memahami makna dan prosedur operasi hitung pembagian. Berikut adalah gambaran kesulitan siswa dalam menyelesaikan operasi hitung pembagian: 

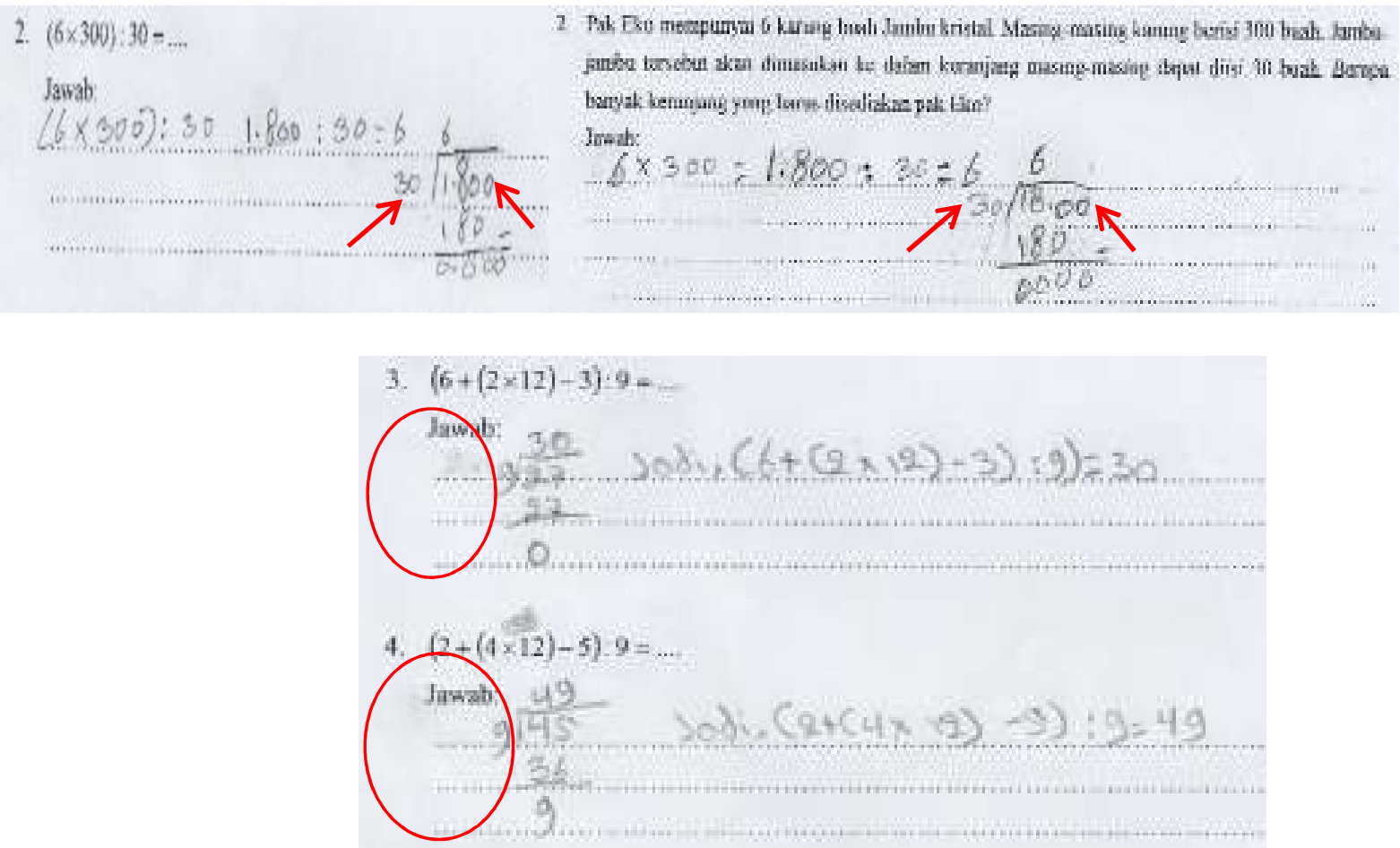

Gambar 10. Kesulitan dalam operasi hitung pembagian

Pada gambar 10 dapat terlihat bahwa kesulitan dalam operasi pembagian. Perhatikan pembagian 1.800 : 30. Subjek kebingungan ketika melibatkan angka 0 dibelakangnya. Perhatikan pembagian 27 : 9. Sudah tepat bahwa hasilnya 3, namun karena tidak faham prosedur, nol yang dibawah hasil pengurangan 27 - 27 ditambahkan ke hasil, jadi 30. Perhatikan pembagian $45: 9$. Awalnya subjek menuliskan angka 4 di hasil. Namun karena tidak faham prosedur, subjek menambahkan angka 9 ke yang didapat dari $(45-36)$ ke jawaban. Subjek kesulitan menyelesaikan operasi hitungan pembagian dengan dua angka.

\section{Kesulitan memahami makna lambang tanda kurung "( $)$ "}

Kesulitan lain yang ditemukan adalah kesulitan dalam memahami lambang tanda kurung "()". Kesulitan memahami makna lambang tanda kurung ini terkait dengan kesulitan siswa dalam memahami konsep matematika yaitu tanda kurung digunakan sebagai bentuk pengelompokkan yang bermakna mendahulukan operasi hitung. Berikut adalah gambaran subjek yang kesulitan memahami makna lambang tanda kurung.

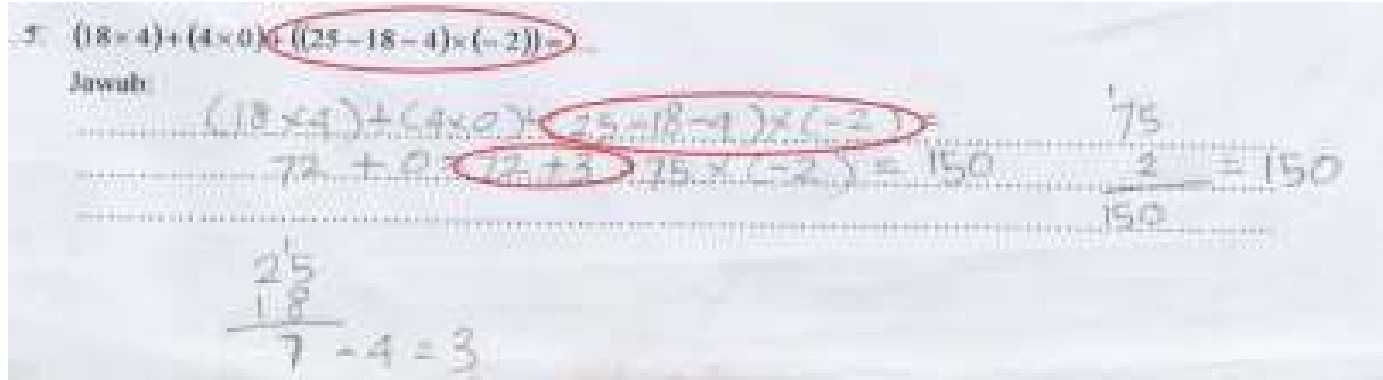

Gambar 11. Kesulitan memahami makna lambang tanda kurung "()"

Berdasarkan gambar 11, terlihat pada jawaban subjek untuk no 5 menunjukkan salah memaknai tanda kurung. Seharusnya yang dioperasikan terlebih dahulu adalah (25-18-4), kemudian hasilnya dikalikan (-2). Selanjutnya hasil ini dijumlahkan dengan hasil $(18 \times 4)$ dan $(4 \times 0)$. Kekeliruan subjek ini mengakibatkan jawaban tidak sesuai dengan permintaan soal. 


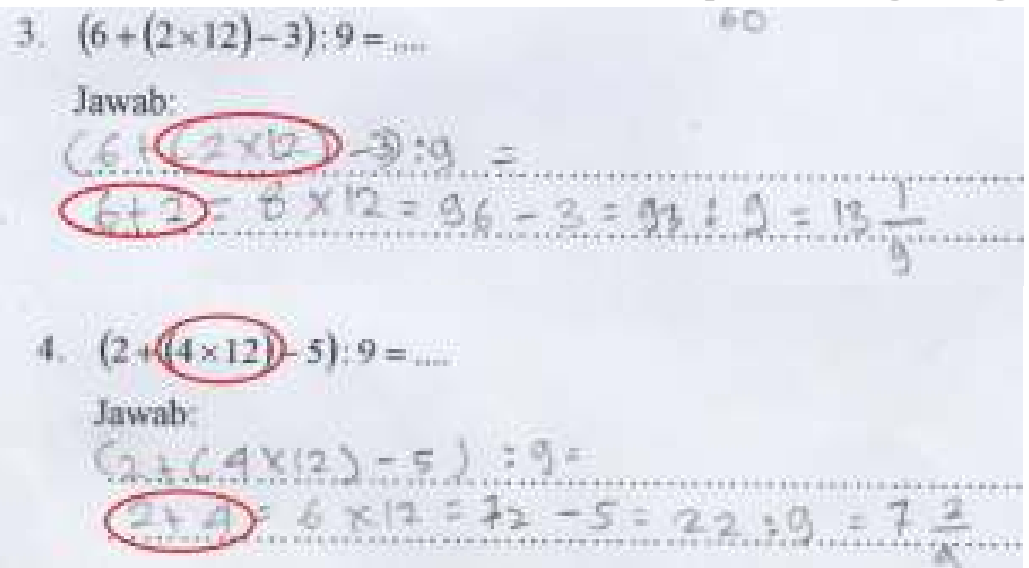

Gambar 12. Kesulitan memahami makna lambang tanda kurung "()"

Berdasarkan gambar 12, terlihat pada jawaban subjek untuk no 3 dan 4 menunjukkan salah memaknai tanda kurung. Untuk nomor 3 terlihat subjek mendahulukan menjumlahkan $(6+2)$. Seharusnya yang dioperasikan terlebih dahulu adalah $(2 \times 12)$, selanjutnya dijumlahkan dengan (6) dan dikurangi (3) atau dikurangi (3) dahulu baru dijumlahkan 6 . kemudian hasilnya dibagi 9. Untuk nomor 4 terlihat subjek mendahulukan menjumlahkan (2+4). Seharusnya yang dioperasikan terlebih dahulu adalah (4 x 12), selajutnya dijumlahkan dengan (2) dan dikurangi (5) atau dikurangi (5) dahulu baru dijumlahkan (2). kemudian hasilnya dibagi 9. Kekeliruan subjek ini mengakibatkan jawaban tidak sesuai dengan permintaan soal.

\section{Simpulan}

Berdasarkan hasil kajian terhadap 6 orang subjek penelitian dengan mencermati dan mengkaji jawaban lembar tugas terkait materi operasi hitung bilangan bulat, diperoleh kesulitan belajar matematika siswa sekolah dasar pada operasi bilangan bulat adalah: 1) siswa kesulitan memahami maksud soal sehingga salah menerjemahkan ke kalimat matematika; 2) siswa kesulitan mengoperasikan bilangan yang memuat tanda negatif; 3) siswa kesulitan memahami makna sama dengan $(=)$; 4) siswa kesulitan melakukan operasi hitung pembagian; dan 5) siswa kesulitan memahami makna lambang tanda kurung "()".

\section{DAFTAR PUSTAKA}

Irham, M. Psikologi Pendidikan Teori dan Aplikasi dalam Proses Pembelajaran. Yogyakarta: Ar-ruz Media, 2014.
Kartikasari, Respina. Analisis Kesulitan Siswa dalam Menyelesaikan Soal Cerita Matematika Pada Siswa SMP. Jurnal Program Studi Pendidikan Matematika Fakultas Keguruan dan Ilmu Pendidikan Universitas Muhammadiyah Surakarta, 2017.

Mulyadi. Diagnosis Kesulitan Belajar. Yogyakarta: Nuha Litera.

Muncarno. (2008). Penerapan Model Penyelesaian Soal Cerita dengan Langkah-langkah Pemecahan Masalah untuk Meningkatkan Prestasi Belajar Matematika Siwa Kelas I SMP. Jurnal Nuansa Pendidikan, Vol.6 No. 1. (2010).

Paridjo. Sebuah Solusi Mengatasi Kesulitan Belajar Matematika. Semarang: Universitas Terbuka, 2012.

Permendiknas RI nomor 22 tahun 2006 tentang standar isi untk satuan pendidikan dasar dan menengah.

Sidik, Geri, S. Analisis Proses Berpikir Dalam Pemahaman Matematis Siswa Sekolah Dasar Dengan Pemberian Scaffolding. Untirta. JPSD, 2 (2), (2016): 192-204.

Sidik, G.S., Nugraha, F., \& Ferisa, D. Analisis Proses Berpikir Siswa Sekolah Dasar Dalam Memahami Aplikasi Operasi Hitung Matematika Dengan pemberian Scaffolding. Jurnal Forum Didaktik, Vol I No 1 (2017): 1-7. Universitas Perjuangan Tasikmalaya.

Sidik, G. S., \& Nugraha, F. Proses Berpikir pada Pemahaman Matematik Siswa Sekolah Dasar Terkait Materi Operasi Hitung Perkalian dan Pembagian Pecahan [The Process of Thinking in Mathematical Understanding of Primary School Students Regarding Counting Operation Materials 
Multiplicat. PEDAGOGIA:

Jurnal

Pendidikan, 8(1), (2019): 45-52.

Skemp, R. Relational Understanding and Instrumental Understanding. Journal of Mathematics Teaching in The Middle School, 12 (2), (2006): 88 - 95.

Soekisno, B.A.R, (2002), Kemampuan Pemahaman Matematik Matematika Siswa
Pada Operasi Hitung Bilangan Bulat

Dengan Strategi Heuristik. (Tesis). Sekolah Pascasarjana, Universitas Pendidikan Indonesia.

Untari, E. Diagnosis kesulitan belajar pokok bahasan pecahan pada siswa kelas V sekolah dasar. Jurnal Ilmiah STKIP PGRI Ngawi, 13(01), $\quad$ (2013): $\quad 1-8$ 